\title{
Effective Leadership-Employee Retention-Work Life Balance: A Cyclical Continuum
}

\author{
*Mrs.Prerna Nair , Dr. (Mrs.) Sonali Malewar \\ Management Dept., MATS University, India \\ Management Dept., MATS University, India
}

\begin{abstract}
It is an interactive paper which has been made to explain the association between leadership and its impact on employee's work-life and employee retention. Both the expressions have gained a lot of magnitude in these day's Organizations. Leadership has been taken up as a foundation in the study as it builds up the essence of our Organizations; Work-life balance has also been addressed as a basic issue for the employees as well the employers. The study undertaken tries to explain in a theoretical and a very interactive way how effective leadership can help balancing the work-life of employees and consecutively leads to help the Organization identify its quality employees and tap their efficiencies for a long-term through employee retention.
\end{abstract}

Keywords: Leadership, Leadership Focus, Work-life Balance, Employee Retention, Leadership Continuum.

\section{ROAD-MAP FOR THE DISCUSSION:}

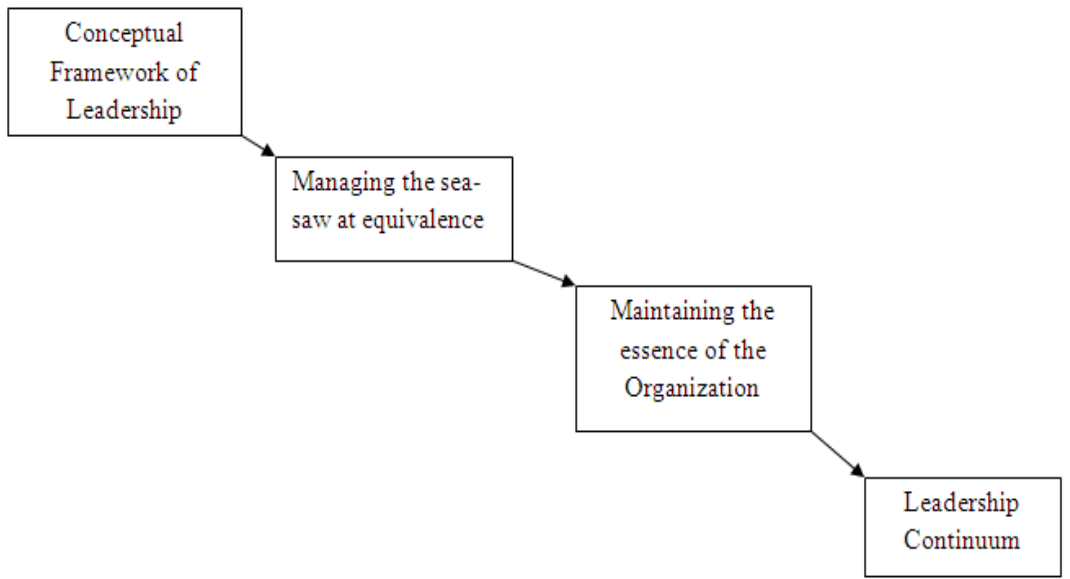

Bringing it all together:

\section{Introduction:}

"Leadership is a continuous process of influencing people's behavior. A Leader breathes life into the group and motivates it towards goals. The lukewarm desires for the achievement are transformed into a burring Poisson for accomplishment."

\section{Rationale behind the Study:}

-Terry

Human in nature have various psychological aspects in his work-life. No two human beings can be similar when they enact as boss in any Organization. Every individual forms his own carcass of business strategy to work on. But do this dynamism in leading styles have a very positive impact on employees who are vital resources of any Organizations?

The Mercer's 2012 Attraction and Retention Survey states that more than 40\% Organizations are expanding their overall workforce in 2012, compared to just $27 \%$ in 2010.

\section{Theoretical Framework:}

"Leadership is the process of influencing and supporting others to work enthusiastically towards achieving the objectives" - Barnard Keys and Thomas Case.

Leadership styles are the patterns of behavior which a leader adopts in influencing the behavior of his followers. The styles are either based on behavioral approach or situational approach of Leadership.

Based on the Behavioral Approach:

1. Power Orientation 
2. Leadership as a continuum

3. Employee-production Orientation.

4. Likert's Management System

5. Managerial Grid.

6. Tri-Dimensional Grid.

Based on Situational Approach:

1. Fiedler's Contingency Model

2. Hursey and Blankard's Situational Model.

3. Path-goal Theory.

Based on the above mentioned approaches, the leaders follow these all styles of Leadership Styles:

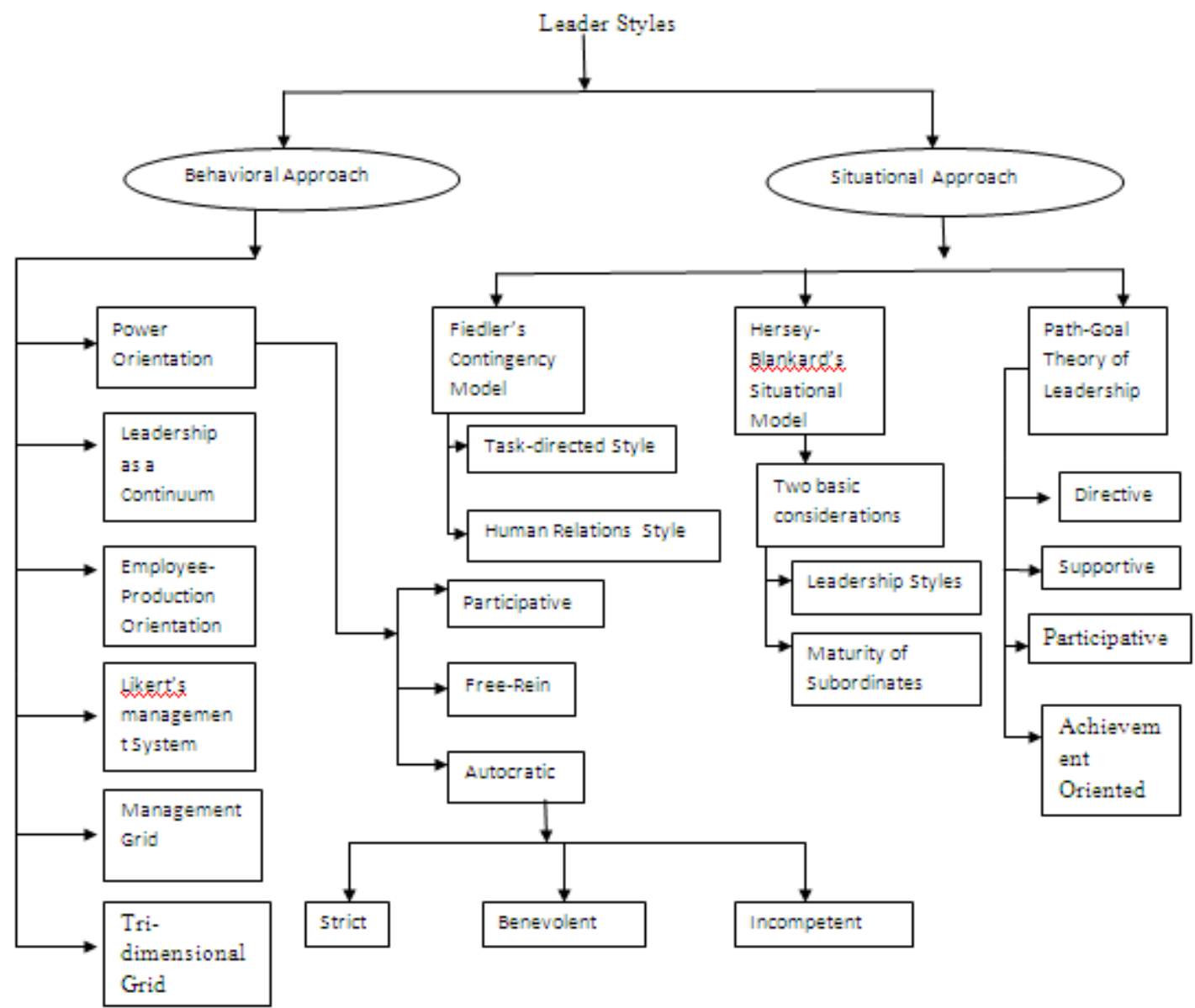

LEADERSHIP STYLES

AND

\section{THE LEADERSHIP FOCUS:}

The Orientation which is adopted by the Leader while observing a particular leadership style. E.g: Task or Relationship orientation, Close control etc.

TRAITS THAT IDENTIFY LEADERSHIP FOCUS:

Trait: "A characteristic feature or a quality distinguishing a particular person or thing". 

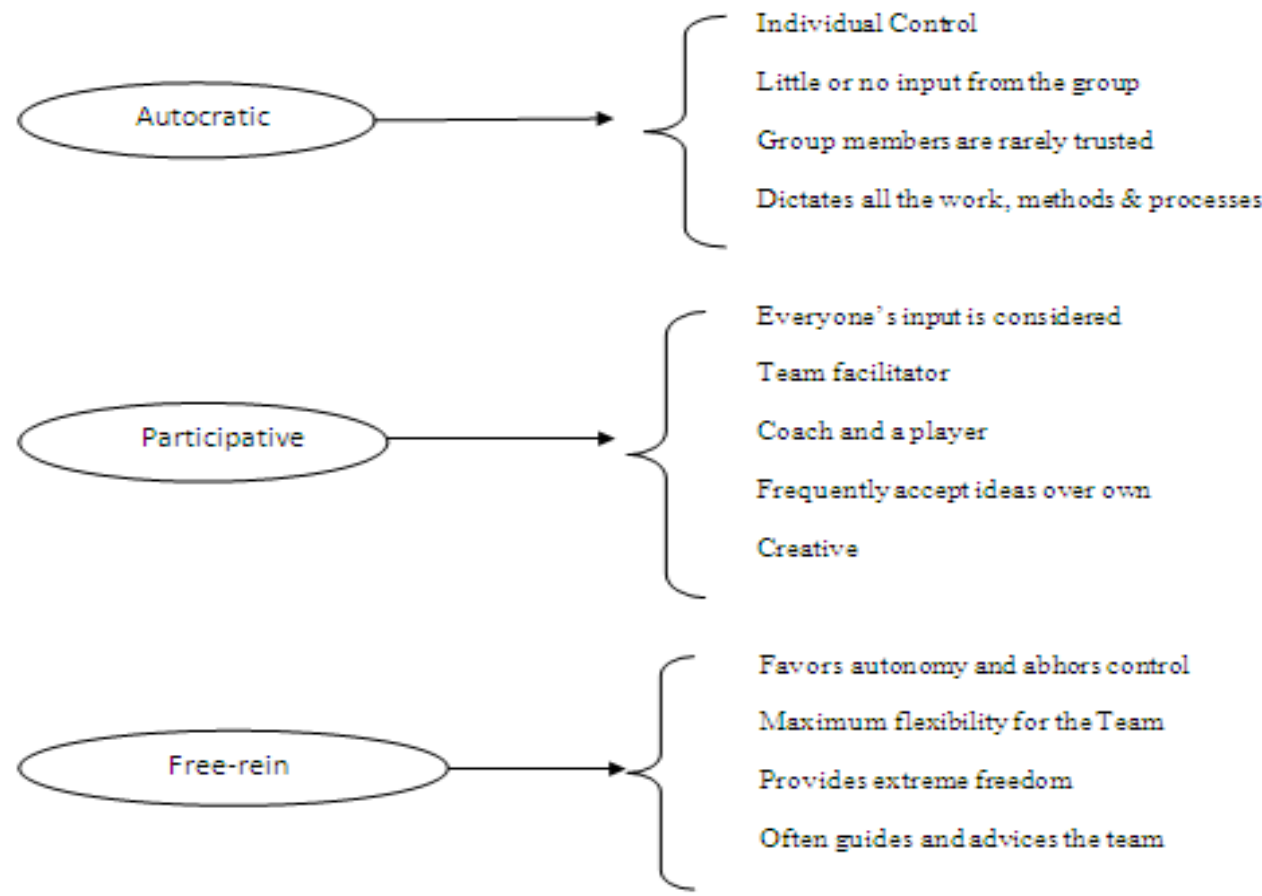

Favors autonomy and abhors control

Maximum flexibility for the Team

Provides extreme freedom

Often guides and advices the team
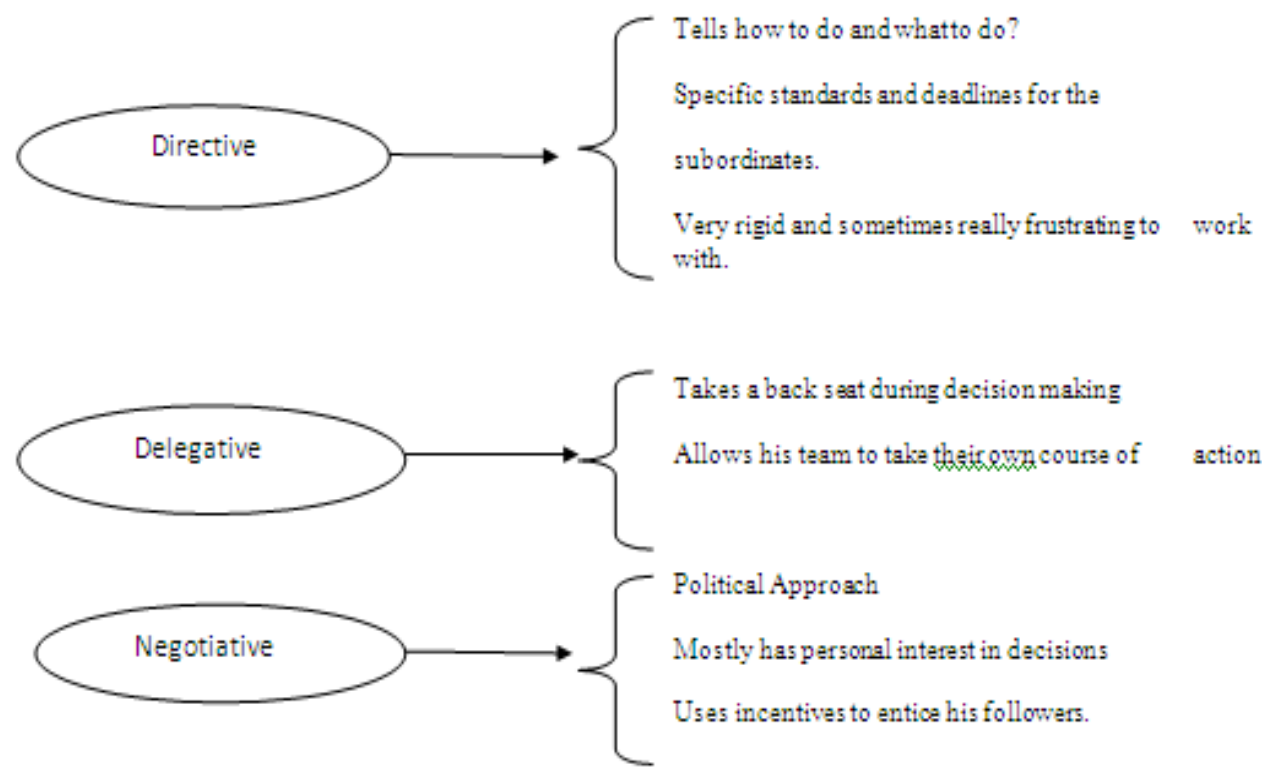

\section{MANAGING THE SEA-SAW AT EQUIVALENCE:}

"Work-life balance, in its broadest sense, is defines as a satisfactory level of involvement or "fit" between the multiple roles in a person's life".

-Hudson, 2005. 


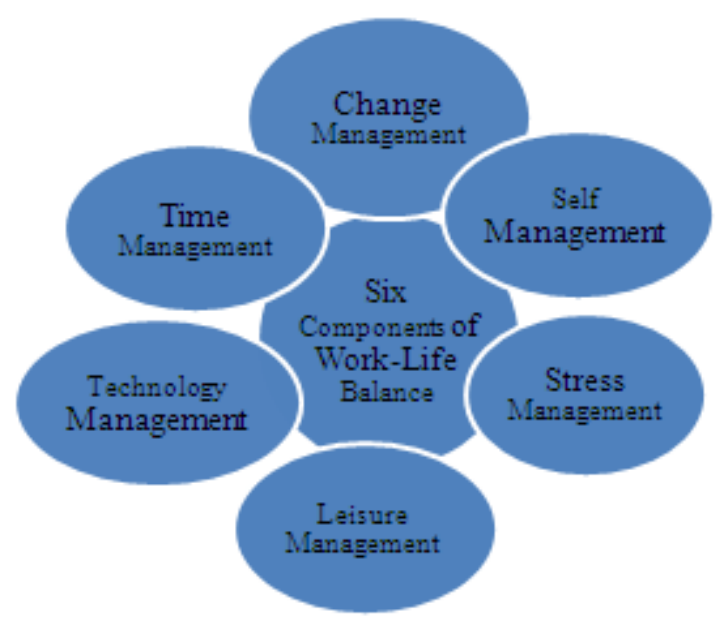

In totality, there are six elements of work-life balance: Technology Management can be said as "Using the technology for human advancements". An approach for transitioning oneself or your team is called as Change Management. Directing oneself towards achievement of the desired objectives is known as Self Management whereas improving the productivity is called as Time Management. Stress Management is maintaining the balance between the work-life balance, fighting the work and issues of personal life. When we work, we tent to see relaxation as an equally important issue therefore; Leisure Management can be understood as realizing the importance of rest and relaxation in one's life.

\section{Employee Retention:}

The employees work in a place where they work in unison to achieve a common goal and it is strongly felt the need to retain the good employees. It is also said that the Organizations where the employees are not serious about their work and where their interests are taken over the interest of their organizations, such corporations are bound to sink.

Employee Retention is important because hiring is not an easy process; a lot of time is spent on hiring the candidates and to get them ready to face the challenging tasks and also to get them adjusted in the corporate culture. When the employees leave the Organizations, they are most likely to join the competitors; the more an employee works in the organization, more readily he will accommodate in the Organizational Culture.

Lucrative salary, comfortable timings, growth prospects are some of the factors which prompt an employee to lookup for a change. The main purpose of retention is to prevent the loss of competent employees for the long term (Chaminade, 2007). It is considered to be a voluntary move by an Organization to create an environment which engages an employee for a long term. Turnover is not only destructive to an Organization, it is rather costly affair.

\section{Leadership and Employee Retention:}
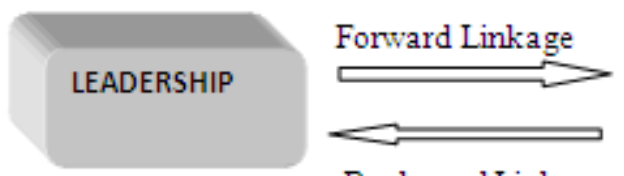

EMPLOYEE

RETENTION

Backward Linkage

Michel (2008), argued that shortage of skilled manpower, economic growth and employee turnover makes employee retention more critical activity for the Organizational managers.

The Concept of Employee Retention:

\section{Employee Retention emerged as a concept in 1970's. Following are some of} the studies done in the context:

Considered to be a voluntary move by an Organization to engage employee

for a long time frame.

The main purpose of retention is to prevent the competent employees from leaving

the Organization as this could have adverse effects on the productivity and service

Chiboiwa, 2009 


\begin{tabular}{|l|l|}
\hline delivery. & \\
\hline $\begin{array}{l}\text { Leadership has always been in research focus as it is not only challenging but } \\
\text { also very dynamic aspect in an Organization: }\end{array}$ & \\
\hline $\begin{array}{l}\text { Leadership is a process of encouraging and helping others to do something of their } \\
\text { own violation, neither because it is required nor because of fear of consequences. }\end{array}$ & Okumbe, 1998 \\
\hline $\begin{array}{l}\text { Management is about developing, planning and controlling of the Organizational } \\
\text { resources while leadership is about the aligning of people to the expected } \\
\text { outcomes of the vision. In order to lead, one must be able to manage and hence the } \\
\text { two are closely related. }\end{array}$ & Gwavuya, 2011 \\
\hline $\begin{array}{l}\text { Generally the followers will emulate the leader's acts and behaviors, thus leading } \\
\text { to achieving the final and desired goals. }\end{array}$ & Mat, 2008 \\
\hline
\end{tabular}

\section{Role of Leadership on Staff Retention:}

\begin{tabular}{|l|l|}
\hline $\begin{array}{l}\text { The role of Leadership and a superior is crucial in staff retention, and argues that } \\
\text { employees leave managers and not the Organizations. }\end{array}$ & Bread well, 2007 \\
\hline $\begin{array}{l}\text { Leaders who understood the business, communicated the goals of an } \\
\text { Organization, and showed empathy towards employees were leaders who } \\
\text { promoted Job satisfaction. }\end{array}$ & $\begin{array}{l}\text { Chen, 2006; Payne, } \\
\text { 2005; Rad \& } \\
\text { Yarmhammadian, } \\
\text { 2006. }\end{array}$ \\
\hline $\begin{array}{l}\text { The reasons stated in the research conducted by Studer in United Kingdom for } \\
\text { leaving the organization were an unsatisfactory connection with his or her } \\
\text { leader. }\end{array}$ & Studer, 2004 \\
\hline $\begin{array}{l}\text { The quality of relationship an employee has with his or her immediate manager } \\
\text { elongates employee's stay in an organization. }\end{array}$ & $\begin{array}{l}\text { Ferreira, 2007, cited } \\
\text { in Micha el 2008 }\end{array}$ \\
\hline $\begin{array}{l}\text { Incompetent Leadership results in poor employee performance, high stress, low } \\
\text { job commitment and turnover. }\end{array}$ & Gwavuya, 2011 \\
\hline $\begin{array}{l}\text { Leadership styles, especially lack of involvement in decision making and } \\
\text { inadequate communication were some of the issues that caused dissatisfaction. }\end{array}$ & Muindi, 2011 \\
\hline
\end{tabular}

\section{Good Leadership Provides:}

- Better vision \& insight

- Offers a new learning each day

- Respects privacy at the workplace

- Follows participatory decision making process.

- Inculcates discipline

- Inspires, trusts, empower employees.

- Communicates the ground realities.

- Works towards providing others with job satisfaction.

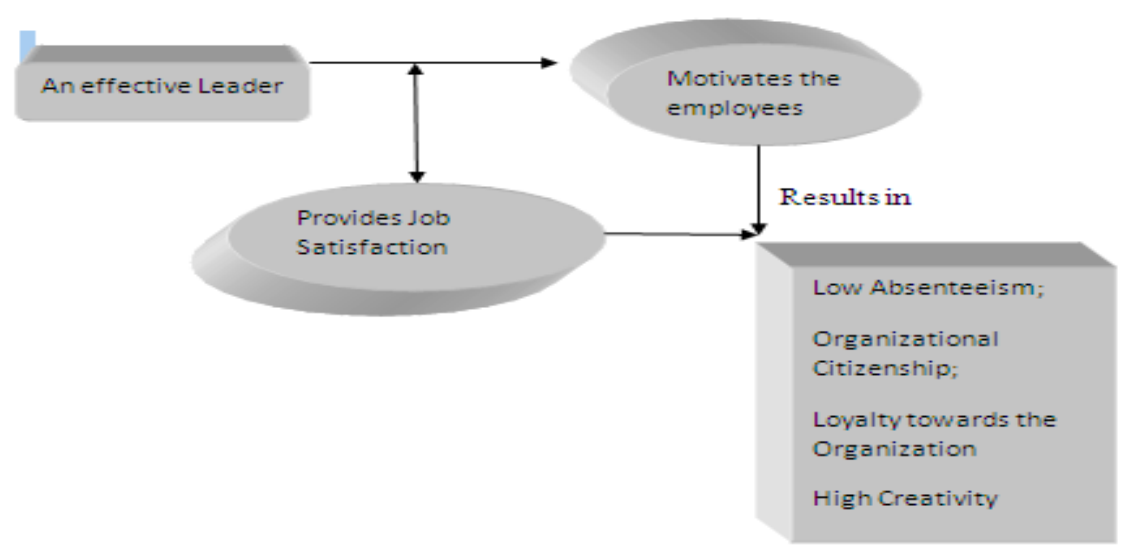


Before any further discussions, it is important to be noted that leader's effectiveness depends upon 3 things:

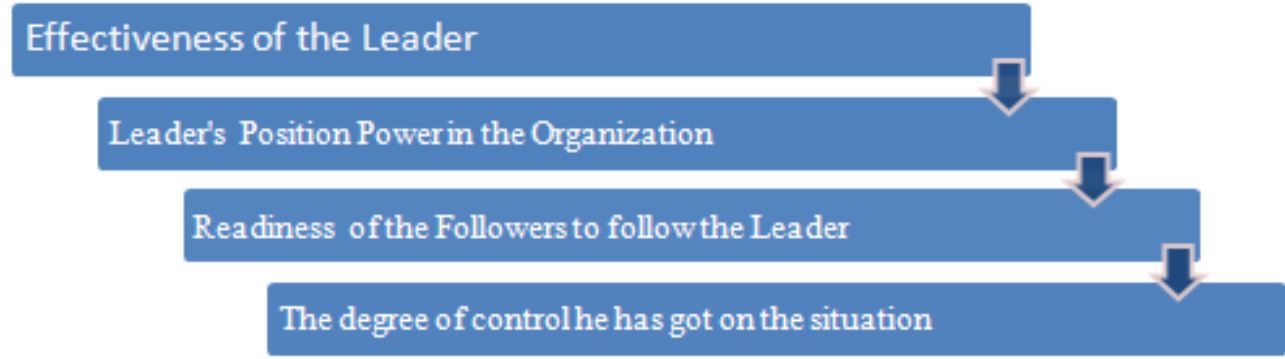

II. Leadership Continuum:

The theory propounded by Tannenbaum and Schmidt (1958) depicts the idea of Leadership continuum and stated variation of leadership practices along the continuum that move from autocracy towards democracy. The continuum states the sequence of action performed with the degree of authority. Eventually if the theory of Tannenbaum and Schmidt is related to X and Y of Mcgregor's, the Superior-centered leadership is towards $\mathrm{X}$ theory and subordinate centered leadership is towards $\mathrm{Y}$ theory. In both the theories, the degree of freedom required and enjoyed by the employees is final outcome which leads to employee retention.

Benefits so far experienced:

- Boss gets a range of options for involvement.

- States criteria for involvement and delegation.

- Focuses decision maker on relevant criteria.

- Emphasis employee development and empowerment.

Disadvantages:

- Involves only the initial step of assigning a task to someone, not the following processes that may determine the effectiveness of the outcome.

- Assumes the manager has sufficient information to determine disposition to self or team.

- Assumes that no societal bonds or politics has impact on organization environment and hence its neutral in nature.

- Simplifies the complicated decisions to simplest solution then reality is.

Source: Tannenbaum, R \& Schmidt, W.H (1973, May/June). How to choose a Leadership Pattern. "Harvard Business Review"

\section{Final Remarks:}

As has been discussed in the undertaken study, different leaders prefer individual patterns and styles of leadership, the styles they choose can depend on the situations, even on the followers they have or can depend upon on other variables such as position power etc. We can finally conclude the complete discussion by summing the different aspects of how synchronized leadership can lead to better and suitable results and also can help to identify good and talented employees. These identified employees can be retained and their efficiencies can be tapped and utilized for Organizational initiatives.

\begin{tabular}{|c|c|c|c|c|c|c|}
\hline $\begin{array}{l}\text { Leader's } \\
\text { Style }\end{array}$ & Orientation & Suitable for & Results in & $\begin{array}{l}\text { Benefits to } \\
\text { Organizations }\end{array}$ & Outcomes & $\begin{array}{l}\text { Final } \\
\text { Outcome }\end{array}$ \\
\hline Autocratic & $\begin{array}{l}\text { Task } \\
\text { Orientation }\end{array}$ & $\begin{array}{l}\text { Operational } \\
\text { Level } \\
\text { Workers }\end{array}$ & $\begin{array}{l}\text { Higher } \\
\text { Productivity }\end{array}$ & High Profits & $\begin{array}{l}\text { Better wages \& } \\
\text { Bonus. }\end{array}$ & \multirow[b]{2}{*}{ 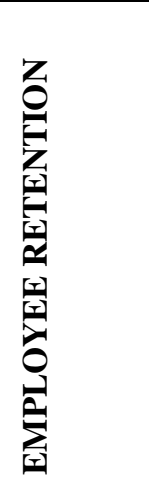 } \\
\hline Participative & $\begin{array}{l}\text { Balanced } \\
\text { Approach } \\
\text { (Employee } \\
+\quad \text { Task } \\
\text { Orientation) }\end{array}$ & $\begin{array}{l}\text { Top \& } \quad \text { Middle } \\
\text { Level } \\
\text { Employees }\end{array}$ & $\begin{array}{l}\text { Better } \\
\text { understanding } \\
\text { amongst } \\
\text { employees \& } \\
\text { Collectivism } \\
\text { followed by } \\
\text { task } \\
\text { Achievement. }\end{array}$ & $\begin{array}{l}\text { Targets } \\
\text { Achievement }\end{array}$ & $\begin{array}{l}\text { Harmonious } \\
\text { Relationships \& } \\
\text { Job satisfaction. }\end{array}$ & \\
\hline
\end{tabular}




\begin{tabular}{|c|c|c|c|c|c|c|}
\hline Free-Rein & $\begin{array}{l}\text { Human } \\
\text { Orientation }\end{array}$ & $\begin{array}{l}\text { Top \& } \\
\text { Middle } \\
\text { Level } \\
\text { Employees }\end{array}$ & $\begin{array}{l}\text { Freedom to } \\
\text { employees; } \\
\text { complete } \\
\text { flexibility to } \\
\text { work. }\end{array}$ & $\begin{array}{l}\text { High } \\
\text { achievements ( } \\
\text { can be } \\
\text { followed if the } \\
\text { employees are } \\
\text { capable and } \\
\text { skilled in their } \\
\text { respective } \\
\text { tasks) }\end{array}$ & $\begin{array}{ll}\text { Autonomy } & \& \\
\text { Employee } & \\
\text { satisfaction } & \\
\text { towards } & \text { his } \\
\text { work itself. } & \end{array}$ & \\
\hline $\begin{array}{l}\text { Directive } \\
\text { Leader }\end{array}$ & $\begin{array}{l}\text { Task } \\
\text { Orientation }\end{array}$ & $\begin{array}{l}\text { Middle \& } \\
\text { Operational } \\
\text { level } \\
\text { Employees }\end{array}$ & $\begin{array}{l}\text { Meeting } \\
\text { deadlines } \\
\text { according to } \\
\text { the direction; } \\
\text { can } \\
\text { sometimes be } \\
\text { harmful to } \\
\text { Knowledge } \\
\text { workers. }\end{array}$ & $\begin{array}{l}\text { Strict control; } \\
\text { Target } \\
\text { achievements; } \\
\text { Better } \\
\text { monitoring of } \\
\text { the employees. }\end{array}$ & $\begin{array}{l}\text { Higher } \\
\text { productivity (if } \\
\text { taken } \\
\text { supportively) } \\
\text { and better } \\
\text { monetary } \\
\text { incentives. }\end{array}$ & \multirow[b]{2}{*}{ 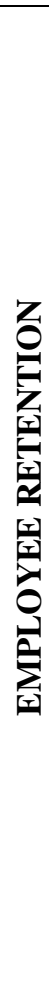 } \\
\hline $\begin{array}{l}\text { Delegative } \\
\text { leader }\end{array}$ & $\begin{array}{l}\text { Relationship } \\
\text { Oriented }\end{array}$ & $\begin{array}{l}\text { Middle } \\
\text { Level } \\
\text { Management }\end{array}$ & $\begin{array}{l}\text { Confidence } \\
\text { building } \\
\text { among } \\
\text { employees as } \\
\text { the leader } \\
\text { takes a back } \\
\text { seat while } \\
\text { decision } \\
\text { making and } \\
\text { supports his } \\
\text { team mates; } \\
\text { treats } \\
\text { employees } \\
\text { with dignity. }\end{array}$ & $\begin{array}{l}\text { Organization } \\
\text { can encash } \\
\text { such } \\
\text { leadership } \\
\text { when the } \\
\text { employees are } \\
\text { serious about } \\
\text { their tasks \& } \\
\text { they respect } \\
\text { their leader. } \\
\text { When } \\
\text { employee base } \\
\text { is loyal then } \\
\text { such results } \\
\text { can be } \\
\text { expected. }\end{array}$ & $\begin{array}{l}\text { Organizational } \\
\text { Citizenship; Job } \\
\text { satisfaction; } \\
\text { Intrapreneurship } \\
\text { can be expected } \\
\text { from such } \\
\text { employees. }\end{array}$ & \\
\hline
\end{tabular}

\section{References:}

[1]. Chaminade B (2007). A retention checklist: how do you rate? www.humanresourcesmagazine.co.au. Accessed, 28 November, 2007.

[2]. Hays S (1999). Generation X \& Y and the art of the reward. Workforce. 78(11): 44-48.

[3]. Edwards, J. R., \& Rothbard, N. P. (2000). Mechanisms linking work and family: Clarifying the relationship between work and family constructs. Academy of Management Review, 25, 178-199.

[4]. Fisher, A. (2001). Is your business taking over your life? Fortune Small Business, 11(9), 32-40.

[5]. Friedman, S. D., \& Greenhaus, J. H. (2000). Work and family-allies or enemies? What happens when business professionals confront life choices. New York: Oxford University Press.

[6]. Greenhaus, J. H., Parasuraman, S., \& Collins, K. M. (2001). Career involvement and family involvement as moderators of relationships between work-family conflict and withdrawal from a profession. Journal of Occupational Health Psychology, 6, 91100 .

[7]. Gwavuya, F. (2011). Leadership Influences on Turnover Intentions of Academic Staff in Institutions in Zimbabwe. Academic Leadership Journal, 9 (1), 1-15.

[8]. Mat, J. (2008). The Influence of Leadership Style on Internal Marketing in Retailing. PhD Thesis. University of Stirling

[9]. Muindi, F.,(2010). The relationship between Participation in Decison making and Job Satisfaction among academic Staff in the School of Business University of Nairobi. Master of Business Administration Thesis, University of Nairobi.

[10]. Michael, S.O. (2008). Using Motivational Strategy as Panacea for Employee Retention and Turnover in Selected Public and Private Sector Organisations in the Eastern Cape Province of South Africa. Master of Commerce Thesis, University of Fort Hare.

[11]. Nielson, T. R., Carlson, D. S., \& Lankau, M. J. (2001). The supportive mentor as a means of reducing work-family conflict. Journal of Vocational Behavior, 59, 364-381.

[12]. Saltzstein, A. L., Ting, Y., \& Saltzstein, G. H. (2001). Work-family balance and job satisfaction: The impact of family-friendly policies on attitudes of federal government employees. Public Administration Review, 61, 452-467.

[13]. Okumbe J. A. (1998). Educational Management: Theory and Practice. Nairobi University Press. 